\title{
Research on the Ability Based Flipped Class Model of Bidding Course of Project Management Major in the University
}

\author{
Lin Wang ${ }^{1, a}$, Yanyu Meng ${ }^{1, b^{*}}$, Mo Liu ${ }^{1, c}$ and Hui Pang ${ }^{1, d}$ \\ ${ }^{1}$ Automobile and Construction Engineering Institute, BeiHua University, \\ Jilin City, Jilin Province, China \\ a94219576@qq.com, b110783881@qq.com, c447206129@qq.com, ${ }^{\text {d } 501287056 @ q q . c o m ~}$ \\ ${ }^{*}$ The Corresponding author
}

Keywords: Engineering management; Innovation; Project bidding; Teaching mode; Flipped class

\begin{abstract}
The higher requirements of Technical personnel is needed in the world knowledge economy challenges.As a new professional training direction of project management important talents, professional education and teaching content of project management major is complex.Only constantly improvement and innovation the work of education and teaching of project management major in universities, the essence of competency based on education is the starting point for the development of the ability to meet the needs of the occupation, emphasizing the results of learning is the ability to acquire rather than just acquire knowledge. This article research that flip the class through the reallocation of teaching time, Students can according to their autonomous learning, will flip the class features into the competency based education teaching, can well solve the problems at this stage which project bidding course teaching, to achieve teaching objectives, enhance students' learning effect and practice ability. Finally, using a class of students as a research objection, the positive significance of this education pattern was validated.
\end{abstract}

\section{Introduction}

In China, the specialty of engineering management, which was established in 1988 by the State Board of education to adjust the specialty of higher education, took the place of the original construction economy and management, real estate development and management. Project management is the management of the project or project construction, where the project refers to civil engineering. Project management is of a project from concept to the formal operation of the whole process (including investment opportunities: a preliminary feasibility study, feasibility study, survey and research, the final design, bidding, procurement, construction and commissioning management etc.).

Analysis of the Current Situation of Project Management Education in China. For a long time, in the higher education of our country, there are some problems in the training of engineering management talents, which focus on theory and practice. The existence of this problem, mainly in the following aspects:

The defects of traditional teaching methods of Engineering Management Specialty in china. The traditional way of teaching in the classroom teaching, in the teaching mode, students' active thinking enthusiasm and creativity are not even culture was killed, and this kind of teaching method to teach the theory and main knowledge as the main teaching content. However, project management is a very practical subject, if only to learn the theory, will lead to the reality, students' practical ability is low, if the teachers lack of practical experience, the problem is more serious.

Practice is not only less, but also difficult to arrange. Because of the reason as everyone knows, many professional practice is difficult to arrange, engineering management is no exception, the practice teaching is complicated, need to rely on assistance and support work of the unit, in the current situation, the effect of practice will inevitably compromised. 
Teaching hardware facilities are relatively backward, relatively high birth. Since the enrollment expansion in 1999, the school hardware facilities and teachers are not synchronous expansion, many school teaching laboratories, student cafeteria, classrooms, student venue is extremely nervous, evening and Sunday school students accustomed to individual school student teacher ratio is more than the provisions of the Ministry of education. These factors affect the improvement of teaching quality to some extent.

From the above analysis, we can see that in order to integrate with the engineering management education is the most advanced in the world, in order to meet the challenge of international cooperation and competition, make our country engineering management talents of world-class management talent ranks, as the reform of the engineering management professional education teaching work, development and innovation of Engineering Management Specialty Teaching imperative.

Project Management Major Teaching Reform and Innovation Goals. The vigorous development of construction industry and city bound together in a common cause great changes in appearance and related industries, especially with the professional qualification system, promote the establishment of modern enterprise system, China's entry into the WTO, level of technical requirements of various types of professional and personal qualities of the construction industry and related industries are increasingly high, especially there will be the growing demand for advanced talents of Engineering management.

Adhere to the overall optimization of the teaching plan. According to the basic courses, professional basic courses and specialized courses of three teaching stages in teaching, teaching arrangements, and properly handle the all-round, basic theory and professional knowledge, main courses and related courses, theory and practice, knowledge and ability, for all students and specific aspects of the relationship between education, mutual penetration and fusion and pay attention to knowledge content, and cohesion between the courses. Arrange the class hours and teaching contents, implement the principle of "fewer but better", and avoid duplicate content, arrange the teaching process more humanistic and social science elective courses, help students to broaden their knowledge, understand the development trend of world science and management to enhance the social environment changes adaptability.

Attach importance to practical teaching. Combined with the ability training, we should make a unified planning of the practical teaching links, and form a systematic practical teaching system. Among them, all the practical teaching links and their contents should be carefully studied, which can fully meet the requirements of cultivating the students' skills and abilities.

Training complex engineering talents. Abandon our higher education students' knowledge structure is not reasonable and the comprehensive quality of talents training mode in weak, large civil engineering technology as the foundation, the legal system as the basis, to economic theory and modern management theory as the core, the talent cultivation techniques and management of the "thick foundation, wide caliber, strong ability and high quality.

\section{The Present Situation and Problems of the Project Bidding Course Teaching}

Project bidding course content by inviting public bidding and bidding two aspects, all colleges and universities of the course focus among 20-30 hours, the majority is not set on the experimental school, curriculum design practice time is not set. Class time to explain the theoretical knowledge, have no time to organize students to discuss the case and simulation training.

Lack of engineering bidding and contract management simulation operation and the application of the relevant software. With the development of electronic bidding platform system, bidding software has been widely used in the construction industry, and some high-end products are also constantly upgrading, the corresponding practice training procedure, coupled with the lack of software, students after graduation to the employer after retraining to posts bidding work, lead enterprises to the students' occupation skill satisfaction decreased. 


\section{The Integrated Teaching Design of Project Bidding Based on the "Ability Based" Flipped Classroom Model.}

The section headings are in boldface capital and lowercase letters. Second level headings are typed as part of the succeeding paragraph (like the subsection heading of this paragraph).

Determine the Objectives of Each Course. According to the curriculum standards, curriculum objectives, combined with teaching content, first clear by the end of the course students can do what things, and work activities, then clear things to do, work activities, need to have what kind of ability, should learn the knowledge, need to have what kind of occupation accomplishment, in order to determine the final goal, ability knowledge goals and occupation quality objectives.

The Selection of Teaching Contents. According to the specific content of the teaching objectives of the project bidding and contract management, the teachers carefully design the main content of the course. To supplement the relevant knowledge of the construction industry in order to adapt to the local construction market economic development curriculum knowledge.

Design of Teaching Situations. There are five ways in which general teaching situations are created. The situation of the story, the activity situation, the life situation, the problem situation and the professional activity situation. The teachers choose the suitable way of creating the way according to the course content, the teaching resources, the student characteristic, the specialty characteristic. The main presentation is video, image, simulation environment and narrative.

Design Teaching Carrier and Choose Teaching Method. Teachers should be based on unit teaching content design the teaching situation according to the students' ability, choice the effective teaching carrier which is the "project", or "task, case, simulation, analogy, activity" and so on. According to the carrier, the teaching environment and the whole course design the step (3) corresponding effective teaching method.

\section{The Project Bidding Courses Ability Standard Reverse the Implementation of Class Teaching Mode.}

The implementation of the classroom teaching model, the following procedures and methods to enable students to master the necessary knowledge, skills and attitudes.

Creating Situations. On the basis of the design of the teaching situation in the unit teaching design scheme, it is necessary to carry out the creation of the teaching situation flexibly and creatively. Teachers need to from the angle of Posts and the application of knowledge in practice, guide students to review the related knowledge and content, leads to new problems; and changes in the teaching situation of deepening in stimulating students' interest in learning; in the simulation or real teaching situation, let students experience the feeling, understanding, mastery of knowledge and skill.

Assigning Tasks. For the problems in the creation of the situation, the teacher with the main content of this lesson to learn a clear learning tasks. Completed by teachers, the need to complete the tasks and learning objectives explain through this task to achieve the implementation of clear, good teaching carrier choice to accomplish this task by the preparatory work (such as learning group, division of labor, material distribution, etc.) for students to set or establish occupation situation, occupation task.

Flip Class Teaching. In the flip classroom teaching, the main highlight of teaching, learning, doing one. In the course of teaching, teachers can guide the teaching of the organization through the joint determination of the product, the work and the results of the activities, so that the students can achieve the unity of theoretical study and practical learning through active and comprehensive learning.

The teacher according to the learning task and content carrier, the first, on the basis of the teaching design curriculum unit (Teaching) training content and process design of the introduction in the teaching of knowledge and skills, gradually in-depth, combined with work (learning) tasks, knowledge interspersed in the teaching carrier (such as case, task, project organization, etc.) the 
implementation of teaching; secondly, according to the selected teaching process, focus on the ability to form, reflect the students' subject, teachers, according to teaching design organization learning ability training, knowledge and induction, occupation literacy training, guidance learning methods, to answer questions, the students found difficult to provide timely remedial instruction, give individual counseling. In teaching, we should embody the integration of teachers' guidance, students' main body, paying attention to the application of knowledge, paying attention to the formation of ability, teaching, learning and doing one.

In the teaching process to allow students to show their ideas (to think, to do), if necessary, can be implemented, so that students see the preliminary results. Then the teacher to explain and demonstrate the correct content. Let the students find their original knowledge (referring to the direct knowledge and experience and indirect knowledge) system and new knowledge, skills docking position, find their own knowledge system deficiencies and shortcomings. Teachers do guidance, repeated training until the correct.

Teaching Evaluation. In the teaching process, prepare and implementation evaluation according to the evaluation methods, the methods of teaching design in each class, teachers should use the degree of students' knowledge, ability, teaching form whether to achieve the goal of sampling and inspection, pay attention to process evaluation. According to the results of the evaluation of teaching reflection, adjust, innovative teaching methods, so that students really understand, learn, and use".

\section{Based On the Practical Application and Effect Analysis of Ability Standard to Flip the Class Teaching Pattern}

Objection of Study. In this study, 2014-2015 school year the first semester of the curriculum of engineering project bidding and contract management of engineering management of 40 class 1 of grade 12 undergraduate students as the research object, based on "ability standard" flip the practical application of classroom teaching mode.

Practice Application of Teaching Mode. Turn to "competency-based" classroom teaching model will help the students improve interest, promote students to solve practical problems, were investigated, more than $80 \%$ of the students think this pattern helps to understand the curriculum knowledge, for the realization of teaching goals and the cultivation of students' vocational ability has a positive role.

The final exam results will be shown in table 1 and 1 in the final exam results of the 2015-2016 semester. The student performance has been greatly improved, and the standard is normal distribution.

To some extent, the application effect of "ability standard" flipped classroom teaching mode is verified.

Table 1 The distribution list of the final exam results of the project tendering and contract management

\begin{tabular}{|c|c|c|c|c|c|}
\hline $\begin{array}{c}\text { method of } \\
\text { examination }\end{array}$ & $\begin{array}{c}\text { closed-book } \\
\text { exam }\end{array}$ & $\begin{array}{c}\text { Results } \\
\text { type }\end{array}$ & \multicolumn{3}{|c|}{ To enter the percentile } \\
\hline garde section & $90-100$ & $80-89$ & $70-79$ & $60-69$ & $0-59$ \\
\hline number of people & 0 & 3 & 10 & 12 & 8 \\
\hline percentage & $0.00 \%$ & $9.09 \%$ & $30.30 \%$ & $36.36 \%$ & $24.24 \%$ \\
\hline
\end{tabular}




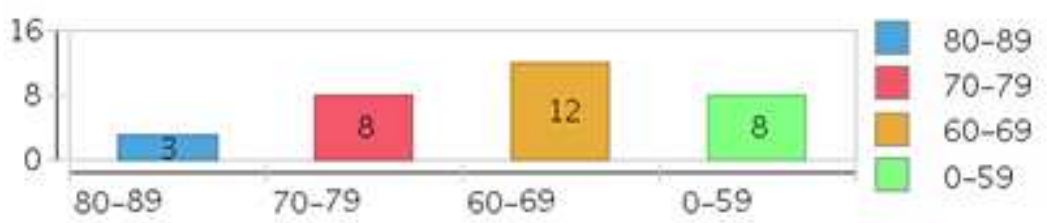

Figure 1. The statistical histogram of the final examination of the final examination of project tendering and contract management

\section{Conclusion}

In combination with the present situation of the teaching work of Engineering Management Professional Education in China. As well as the practice of project management professional teaching, innovation of teaching work in Universities of engineering management professional education are useful discussion. Based on the theory and practice research, it is concluded that in the curriculum the education of engineering project bidding based on the teaching method reform "competency-based" flip the classroom teaching model for the realization of teaching goals and the cultivation of students' vocational ability has a positive role.

\section{References}

[1] Yuan Shiying, Research on the training mode of diverse talents and the cultivation of individualized talents, J. Chinese University Education.2003.3.

[2] Qin Zuze et al, Rational thinking on the integration of engineering education and humanistic quality education, J. Chinese University Education.2003.3.

[3] Hu Lei, It is based on the construction and application of the teaching mode of higher vocational programs, J. Journal of Teaching and Management.2015(29): 37-40.

[4] Liu Liang, Problems and improvement measures in the teaching of bidding and contract management of construction projects, J. Research in Higher Education.2015(3):29-33.

[5] Wang Xiao ai, The reform of teaching and bidding and contract management is discussed, J. In the West of the New. 2015(9):136. 